\title{
Cough in Exercise and Athletes
}

JH Hull ${ }^{a}$ JW Dickinson ${ }^{b}$, AR Jackson ${ }^{b}$

${ }^{a}$ Department of Respiratory Medicine, Royal Brompton Hospital, London, SW3 6HP

${ }^{b}$ School of Sport and Exercise Sciences, University of Kent, Medway Building, Chatham, Kent, ME4 4AG

\section{Corresponding author:}

Dr. James H Hull FRCP PhD

Department of Respiratory Medicine

Royal Brompton Hospital

London

SW3 6HP

E-mail: j.hull@rbht.nhs.uk

Tel: +44 2073518043

Word Count: 3125

Key Words: athlete, cough, asthma, larynx, wheeze 


\section{ABSTRACT}

Cough is the most common respiratory symptom reported by athletes and can significantly impact on health status, ability to train and athletic performance. The presence of cough in an athlete is typically taken to indicate exercise-induced bronchoconstriction (EIB), yet in many athletes with chronic cough there is no objective evidence of airway hyper-responsiveness (AHR) or heightened airway inflammation. Moreover, cough in athletes often fails to respond to a therapeutic asthma strategy, thus further work is urgently needed to progress our understanding of the pathophysiology of exercise-associated cough in this unique population.

This article provides an overview of the current state of knowledge of exercise-associated cough in athletes. The article summarises our understanding of pathophysiological basis of cough in this context and provides a pragmatic clinical approach to this problem. 


\section{Introduction}

Exercise-associated cough is frequently reported by athletic individuals and can significantly impact their health status and ability to prepare for and perform sport [1]. Indeed, troublesome cough is so commonly encountered in certain sports that a number of colloquialisms have arisen to describe this condition, e.g. 'locker room' cough and 'swimmers hack'.

In athletic individuals, exercise-associated cough is often taken to indicate the presence of exercise-induced bronchoconstriction (EIB), prompting initiation of asthma treatment. However, studies in athletes often reveal a poor relationship between the presence of cough and ElB, when objective testing is employed [2-5]. Recent studies substantiate this position by revealing that cough is equally prevalent in athletes with or without EIB $[2,6,7]$ and there is now improved recognition that cough is a key symptom in other prevalent exercise-associated respiratory disorders, such as exercise-induced laryngeal obstruction (EILO) ([8]).

Several studies have advanced our understanding of cough in athletes. Specifically, exerciseassociated cough appears more prevalent in endurance athletes [4] and particularly those competing in winter sports [3]. Coughing also appears to become more prominent and problematic over the course of an athlete's competitive season [6]. Regardless, our knowledge in this area still remains at a relatively embryonic stage and there are very few well-conducted treatment trials for cough in athletic populations [9]. 
This review aims to provide an overview of cough in athletic individuals, with a focus on the impact, possible pathophysiological mechanisms and current treatment options. The article is based on a presentation given at the $9^{\text {th }}$ International Symposium on Cough.

\section{Exercise and cough}

Exercise is recognized to place a unique set of physiological demands on the respiratory system. Indeed, even low levels of physical activity mandate an immediate increase in minute ventilation $\left(V_{E}\right)$, whilst strenuous exercise can exert significant physical and chemical stress on the airway tract.

Moreover, it is now well established that high-intensity exercise, particularly when performed in noxious environments (e.g. cold air or some swimming pool environments) can precipitate airway changes; with features in keeping with an inflammatory 'injury' profile [10] and a 'dysfunctional' physiological response, i.e. promoting airways hyper-responsiveness (AHR) [11]. Having said this, whilst it might be assumed that exercise would always act as a pro-tussive stimulus, studies reveal that exercise may in fact attenuate this symptom and down-regulate cough hyper-sensitivity [12].

It is now over thirty years since Banner and Green [13] found that healthy individuals reported cough after exercising in cold weather and investigated the effects of hyperpnoea on cough [14]. Individuals with normal spirometry and no evidence of AHR performed hyperpnoea in ambient $\left(25^{\circ} \mathrm{C}\right)$, subfreezing $\left(-16^{\circ} \mathrm{C}\right)$, warm dry $\left(39^{\circ} \mathrm{C}\right)$ and warm fully-saturated $\left(39^{\circ} \mathrm{C}\right)$ conditions for four minutes at ventilatory rates similar to those that occur during strenuous exercise. The study revealed that coughing occurred predominantly following rather than during hyperpnoea and that 
cough frequency only exceeded baseline values when the environmental conditions promoted airway heat and water loss i.e. in the ambient, subfreezing and warm dry conditions. This aligns with the clinical observation that, for the majority of individuals, troublesome cough is a postexercise phenomenon $[6,15]$.

In an elegant study, Lavorini and colleagues [16] compared a cough threshold (an index of cough sensitivity) in healthy, physically active individuals, by increasing nebulizer outputs of ultrasonically nebulized distilled water (fog) in three different conditions; a control condition, cycling at $80 \%$ anaerobic threshold and during voluntary isocapnic hyperpnoea (performed at a similar $V_{E}$ to the cycling condition). They found that cough (assessed audio visually by a trained observer), in the context of this experimental protocol was attenuated during exercise and to a similar extent during hyperpnoea. The authors concluded that exercise or voluntary hyperpnoea exerted inhibitory influences on coughing.

\section{Mechanism(s) underlying exercise associated cough}

Widdicombe and colleagues [17] previously highlighted several putative pathophysiological mechanisms that are likely to be relevant in exercise associated cough (Table 1). Undoubtedly, strenuous physical activity mandates a specific physiological response that can impact, in numerous ways, on cough regulatory mechanisms. These include direct effects from hyperpnoea and distension stress, acting on both the airway and chest wall; impact from local mediator release (e.g. substance $P$, adenosine triphosphate $[A T P])$ and changes in airway surface properties (e.g. osmolarity); direct activation of neural pathways via either chemical or mechanical factors and the 
impact of systemic alterations (e.g. sympathetic activity and catecholamine release) with increased cardiac output and pulmonary blood flow (Figure 1).

Widdicombe and colleagues [17] reported that during exercise or voluntary hyperpnoea, it is likely that slowly adapting stretch receptors (SARs) in the airway play a role in modulating the cough response when breathing depth is increased. This notion is supported in a study by Nishino et al. [18] indicating lung inflation with continuous positive airway pressure (CPAP) increased the cough reflex in anaesthetised humans. Lung distortion / stretch can cause the release of prostaglandins, which have been shown to provoke cough through their effects on airway c-fibres [19].

In contrast, an increase in pulmonary blood flow, arising during exercise, may lead to cough inhibition. Paintal [20] found that, in a feline animal model, increased pulmonary blood flow stimulated pulmonary c-fibre receptors. In animal studies, pulmonary [21] and bronchial [22] cfibres have been shown to inhibit cough via their activation from an increase in pulmonary blood flow.

A key factor in the development of cough in response to cold dry air exposure, relates to changes in the airway surface liquid properties and local irritation of airway mediated receptors. Typically, inspired air is conditioned (i.e. warmed and humidified) through heat exchange in the nasal cavity, before entering the more distal airway. This mechanism is compromised however during exercise. Specifically, when $V_{E}$ exceeds a certain level (approximately $30 \mathrm{~L} / \mathrm{min}$ ) there is a switch from a nasal to oral predominant breathing pattern. This alteration has impact for the conditioning of air and in cold weather, the air temperature travelling through the trachea and bronchi can be as low 
as $20^{\circ} \mathrm{C}$ [23]. The respiratory water loss and resultant airway surface mucosal drying may lead to both physical and chemical activation of cough receptors [14]. It also proposed that cough receptors may respond directly to thermal stimuli or to mediators that are produced or released as a consequence of this airway drying and cooling [6]. Ternesten-Hasseus et al[24] found that following an exercise challenge in cold air $\left(4^{\circ} \mathrm{C}\right)$, in which participants cycled for 4 minutes at $50 \%$ of their maximal voluntary ventilation (MVV), cough sensitivity to capsaicin was increased in a group of patients with exercise-induced dyspnoea but without ElB. No such changes were observed in a control group.

Sue-Chu et al. [25] found that cough reflex sensitivity to capsaicin was not related to either AHR or EIB, suggesting that exercise was the key factor inducing cough, with no change in the cough reflex. They also observed that some athletes who experience an increase in cough 2-8 hours following the exercise. Sue-Chu et al. [25] proposed that cold air inhalation during exercise could induce neurogenic inflammation with the release of tachykinins and kinins accompanied by the release of long acting mediators such as leukotrienes, which could trigger cough receptors without impacting cough reflex sensitivity. Thus, there may be a dual early and late response pattern, such as the one observed after allergic challenge and physical exertion in asthmatic subjects.

\section{Mechanism(s) underlying cough in athletes}

The mechanisms underlying exercise-associated cough in athletes remain to be determined, however several factors are likely to be relevant. In athletic individuals, the respiratory system is repeatedly exposed to a number of factors that may promote development of cough hyper-

sensitivity (Table 1 and Figure 1). Indeed, for elite athletes their 'occupation' clearly mandates 
regular, sustained hyperpnoea and often exposes the respiratory system to potentially noxious environmental stimuli (e.g. cross-country skiing or indoor swimming pool environment) and allergens. As outlined above, both inflammatory and mechanical irritant effects, arising from breathing cold, dry air, can trigger alterations in the cough reflex [19].

Cough in athletes is frequently taken to be indicative of EIB. Anderson and Holzer [29] observed that cough often occurs after exercise in relation to bronchoconstriction. However, as discussed above, whilst cough is often associated with EIB, many athletes without EIB also report exerciseassociated cough. It has also been shown that despite EIB being attenuated by the administration of inhaled $\beta$-2-agonist, cough can remain a prominent symptom [13]. Moreover, Drobnic et al [30] found a high prevalence of post-exercise cough, in athletes, irrespective of AHR.

Chronic hyperpnoea in noxious environments may lead to airway irritation or inflammation leading to an 'airway-injury' type picture that is likely to modulate the sensory response of cough receptors $[6,10]$. Repeated exercise in the cold may result in a continuous cycle of injury and repair, leading to chronically inflamed airways with the potential for cellular airway changes [31]. These modifications to airway structure and function may play a key role in the increased prevalence of AHR and cough observed in athletes [6] [32]. Kennedy et al [33] observed significant changes in cough symptoms, which were related to the change in sputum neutrophils and the total yearly duration of training performed. Less is known about the role of neutrophils in eliciting and driving a heightened chronic cough response. 
There are number of other factors likely to be relevant in the development of cough in athletes. Nasal disorders are common in athletes and are certainly highly prevalent in elite swimmers, with studies showing that $25-74 \%$ of swimmers complain of chronic rhinitis symptoms [34-36]. An upper airway cough syndrome (UACS) is widely reported as being relevant in the aetiology of a proportion of cough chronic patients $[37,38]$. It is presumed that in many cases chronic cough arises from irritation and inflammation of the upper airway structures, directly stimulating cough receptors [37] and development of a sensitised cough reflex via nasal sensory nerves [39].

Gastroesophageal reflux disease (GERD) is also likely to be relevant in many cases of cough in athletes. Reflux is highly prevalent in athletes, particularly those participating in endurance sports $[40,41]$. In the general population, numerous studies have implicated GERD in the pathogenesis of cough, via direct 'reflux' actions but also by 'reflex' activation of pro-tussive pathways in the lower oesophagus [42]. The impact of GERD on cough in athletes however has yet to be formally studied.

Finally, laryngeal hypersensitivity and dysfunction [43] is likely to be relevant in many cases of cough in athletes. It is now recognised that transient and inappropriate closure of the larynx during exercise, a condition termed EILO, appears to be a prevalent [44] cause of cough in athletes with treatment refractory or unexplained respiratory symptoms and is often mis-diagnosed and then mis-treated as asthma [8]. Improved recognition of this condition is important to facilitate targeted treatment and avoid administration of medications that may exacerbate symptoms [45].

\section{Cough in Athletes}


Athletes frequently report troublesome respiratory symptoms [26] and of these exerciseassociated cough is extremely common (Table 2). Turcotte et al. [3] examined the frequency of respiratory symptoms in one hundred high-level athletes, principally to determine if respiratory questionnaires were reliable predictors of AHR / asthma. They found that questionnaires regarding symptoms and their associated nociceptive sensations may be able to help to detect AHR in both athletes and controls.

Rundell et al. [2] compared the efficacy of self-reported symptoms for predicting EIB with postexercise challenge pulmonary function test results in 158 elite winter athletes. This study revealed that post-exercise cough was the most common symptom reported, however, cough was not found to be predictive of EIB and the authors warned that the use of symptoms, such as cough, in predicting the presence of EIB led to a significant risk of mis-diagnosis.

In a study of the Great British Olympic team [5], cough was the most common symptom reported in athletes with a previous history of asthma. However again when a group of 228 elite athletes attended screening for EIB, using a eucapnic voluntary hyperpnoea challenge, $85(37 \%)$ athletes reported experiencing cough during and/or after training and the presence of cough was not predictive of AHR [27]. Similarly, a study in elite British Soccer players, with a previous history of an asthma related diagnosis, cough associated with soccer was reported in almost half of athletes assessed, however exercise-associated cough was not predictive of a positive indirect airway challenge [28]. 
Turmel et al [6] evaluated seasonal variability in cough in a cohort of 53 elite winter sport athletes and 33 sedentary controls. Participants were required to complete a respiratory questionnaire and a capsaicin cough provocation test during the summer, autumn and winter. In all seasons, athletes had significantly more self-reported cough in the first hour post exercise cessation than the nonathlete control group. The prevalence of self-reported post-exercise cough was higher during the winter in the athlete group compared to in the summer (71\% compared to $44 \%$ prevalence respectively), whereas in the control group this remained unchanged (18\% during winter, $16 \%$ summer). In addition, some athletes also reported troublesome cough occurring 2-8 hours' post exercise, indicating the presence of a late cough response (22\% prevalence), although this was not observed in the control group (2\%). Despite this values for cough reflex sensitivity (to capsaicin) were lower across the summer, autumn and winter in athletes $(91+\underline{+4} \mu \mathrm{M}, 68+4 \mu \mathrm{M}, 42 \pm 5 \mu \mathrm{M})$, when compared to control participants at commensurate time points $(123 \pm 5 \mu \mathrm{M}, 145 \pm 4 \mu \mathrm{M}$, $138 \pm 5 \mu \mathrm{M})$.

\section{Impact of cough in athletic performance}

It is currently unclear what impact cough has on athletic performance. Cough is unlikely to impact athletic performance during a single bout of exercise, given the fact that, in the majority of cases, this symptom arises as a post-exercise phenomenon. This acknowledged, post-exercise cough has the potential to have a significant effect on recovery and thus subsequent performance during training and competition. Kennedy et al. [33] demonstrated that, in female cross-country skiers, adverse effects of cough worsened as the season progressed, shown by a reduction in all domains of the Leicester Cough Questionnaire (LCQ); with 10 of the 18 skiers experiencing a deleterious effect from their cough, over a year. A high proportion of athletes also reported that as the season progressed their cough had a greater impact on their sleep quality. Although the authors did not 
investigate whether sleep quality impacted on exercise performance, impaired sleep quality is known to impair exercise performance [46].

\section{Evaluation and treatment of cough in athletes}

The assessment of cough in an athletic individual should proceed as per standard clinical assessment for any individual with new respiratory symptoms [37] however certain aspects are pertinent to consider in this unique population; i.e. consideration of prevalent underlying respiratory causes (e.g. EIB and EILO) and the impact of treatment side-effects and anti-doping considerations [9].

Assessment should focus on establishing the presence of clinical features that support an underlying diagnosis of asthma / EIB [47]. Likewise, consideration should be given for features that may indicate EILO, e.g. inspiratory stridor or dyspnoea and cough that occur / are maximal during strenuous exercise and rapidly settle on exercise cessation [45]. Certain conditions (e.g. swimming-induced pulmonary oedema) are associated with classical clinical features that can be established from a thorough clinical history [48].

Objective testing (e.g. indirect bronchoprovocation tests) should be performed to determine if an athlete, presenting with cough, has evidence of airway hyper-reactivity and detection of EIB should prompt treatment as per guideline recommendations [47]. Cough-hypersensitivity testing however does not have a key role in standard clinical assessment. 
Very few studies have evaluated treatments for cough in athletes in a robust and reliable fashion. The recent CHEST Guideline and Expert Panel Report [9] highlights this fact, however does acknowledge there are a small number of studies that have specifically evaluated the effect of treatments on cough in athletic individuals (Table 3). At this time therefore, until further studies have been performed in athletes, current guidelines for the general population should be applied for the evaluation and treatment of cough in athletes, taking into account specific training context and anti-doping regulations [9]. In this respect, it is an athlete's responsibility to ensure no medication is taken that is prohibited, however detailed information can be found regarding antidoping regulations for any medication at www.globaldro.org.

It is important to assess and treat any contribution from sinonasal disease. In swimmers Gelardi et al. [35] showed that neutrophilic nasal inflammation decreased as a result of wearing a nose clip during swim training, over a 30 day period. There are also anecdotal reports of regular saline nasal douching, acting to reduce impact of cough symptoms from rhinitis. Treatment with oral antihistamines and nasal steroids may also be indicated.

Cough resulting from GERD can be addressed in some cases by making adjustments to exercise load along with lifestyle and dietary modifications [49], however where this is not possible or not effective, pharmacological intervention may be necessary and should again be guided by standard guideline recommendations. Consideration of treatment for non-acid reflux is important and typically this may involve use of an alginate antacid formulation taken pre-exercise and post meal. 
Laryngeal dysfunction can be managed through a combination breathing pattern retraining and inspiratory muscle training. Breathing pattern training focuses on promoting diaphragmatic breathing and improved breathing control, in order to promote a degree of neuromuscular reeducation [50]. Breathing technique work can be performed in conjunction with inspiratory muscle training which has been shown to attenuate the symptoms of EILO [51]. If a conservative approach is not successful, then a surgical approach may be indicated in select cases and following continuous laryngoscopy during exercise testing [52].

A small number of studies suggest that the use of a facemask, incorporating a heat and moisture exchanger, may attenuate EIB [53-56]. If these masks are able to protect against EIB, through warming and humidifying inspirate, they may also have the potential to decrease the incidence of cough amongst athletes engaging in winter sports. This has yet to be studied.

The role of an anti-tussive strategy targeting 'neurogenic' modulation in cough has not been studied in athletes. Certainly, many of the potential side-effects of the treatments most frequently employed (e.g. fatigue, postural dizziness with Gabapentin) would confound successful use in a competitive athletic population and these treatments should be introduced with caution.

\section{Conclusion}

Exercise-associated cough is frequently reported by athletes of all abilities, and in the chronic setting likely has long-term implications for performance. Despite several studies evaluating the impact of exercise on cough, there remains a paucity of data regarding the characteristics, underlying mechanisms and best treatment approach of this symptom in athletes. Exerciseassociated cough is a poor predictor of EIB and therefore the presence of cough during or after 
exercise should not be solely attributed to asthma or EIB. Further research is urgently needed to progress our understanding of the impact of exercise-associated cough and how best to prevent its development and to facilitate new treatments. 


\section{REFERENCES}

[1] R. Katz, S. Siegel, G. Rachelefsky, Chronic cough in athletes, Clin. Rev. Allergy Immunol. 6 (1988) 431-441.

[2] K.W. Rundell, J. Im, L.B. Mayers, R.L. Wilber, L. Szmedra, H.R. Schmitz, Self-reported symptoms and exercise-induced asthma in the elite athlete., Med. Sci. Sports Exerc. 33 (2001) 208-213. doi:10.1097/00005768-200102000-00006.

[3] H. Turcotte, J.B. Langdeau, D.M. Bowie, L.P. Boulet, Are questionnaires on respiratory symptoms reliable predictors of airway hyperresponsiveness in athletes and sedentary subjects?, J. Asthma. 40 (2003) 71-80. doi:10.1081/JAS-120017209.

[4] H. Turcotte, J.B. Langdeau, G. Thibault, L.P. Boulet, Prevalence of respiratory symptoms in an athlete population, Respir. Med. 97 (2003) 955-963. doi:10.1016/S0954-6111(03)001239.

[5] J. Dickinson, G. Whyte, A. McConnell, M. Harries, Impact of changes in the IOC-MC asthma criteria: a British perspective, Thorax. 60 (2005) 629-632. doi:10.1136/thx.2004.037499.

[6] J. Turmel, V. Bougault, L.-P. Boulet, Seasonal variations of cough reflex sensitivity in elite athletes training in cold air environment., Cough. 8 (2012) 1-8. doi:10.1186/1745-9974-8-2.

[7] M. Bordeleau, J. Turmel, L.-P. Boulet, Effects of ipratropium on exercise-induced cough in winter athletes: a hypothesis generating study., Phys. Sportsmed. 42 (2014) 7-13.

[8] E.W. Nielsen, J.H. Hull, V. Backer, High prevalence of exercise-induced laryngeal obstruction in athletes, Med. Sci. Sports Exerc. 45 (2013) 2030-2035. doi:10.1249/MSS.0b013e318298b19a.

[9] L.-P. Boulet, J. Turmel, R.S. Irwin, K.W. Altman, A.F. Barker, S.S. Birring, F. Blackhall, D.C. 
Bolser, L.-P. Boulet, S.S. Braman, C. Brightling, P. Callahan-Lyon, A.B. Chang, T. Cowley, P. Davenport, S. Ebihara, A.A. El Solh, P. Escalante, A. Feinstein, S.K. Field, D. Fisher, C.T. French, P. Gibson, P. Gold, C. Grant, S.M. Harding, A. Harnden, A.T. Hill, R.S. Irwin, P.J. Kahrilas, K.A. Keogh, K. Lai, A.P. Lane, K. Lim, M.A. Malesker, P. Mazzone, L. McGarvey, M.H. Murad, P. Newcombe, H.Q. Nguyen, J. Oppenheimer, M. Rosen, B. Rubin, J.H. Ryu, J. Smith, S.M. Tarlo, A.E. Vertigan, G. Wang, M. Weinberger, K. Weir, Cough in the Athlete, Chest. 151 (2017) 441-454. doi:10.1016/j.chest.2016.10.054.

[10] P. Kippelen, S.D. Anderson, Airway injury during high-level exercise, Br. J. Sports Med. 46 (2012) 385-390. doi:10.1136/bjsports-2011-090819.

[11] V. Bougault, J. Turmel, L.P. Boulet, Airway hyperresponsiveness in elite swimmers: Is it a transient phenomenon?, J. Allergy Clin. Immunol. 127 (2011) 892-898. doi:10.1016/j.jaci.2010.11.003.

[12] J. Widdicombe, V. Singh, Physiological and pathophysiological down-regulation of cough, Respir. Physiol. Neurobiol. 150 (2006) 105-117. doi:10.1016/j.resp.2005.04.013.

[13] A.S. Banner, J. Green, Effects of hyperpnea with cold air in subjects with exercise induced cough, Am. Rev. Respir. Dis. Abstract (1984) 129-261.

[14] A.S. Banner, J. Green, M. O'Connor, Relation of respiratory water loss to coughing after exercise, N. Engl. J. Med. 311 (1984) 883-886.

[15] H.L. Petsky, J.A. Kynaston, M. McElrea, C. Turner, A. Isles, A.B. Chang, Cough and exhaled nitric oxide levels: what happens with exercise?, Front. Pediatr. 24 (2013) 1-7. doi:10.3389/fped.2013.00030.

[16] F. Lavorini, G.A. Fontana, E. Chellini, C. Magni, R. Duranti, J. Widdicombe, Desensitization of the cough reflex by exercise and voluntary isocapnic hyperpnea, J. Appl. Physiol. 108 (2010) 
1061-1068. doi:10.1152/japplphysiol.00423.2009.

[17] J. Widdicombe, G. Fontana, P. Gibson, Workshop - Cough: Exercise, speech and music, Pulm. Pharmacol. Ther. 22 (2009) 143-147. doi:10.1016/j.pupt.2008.12.009.

[18] T. Nishino, K. Sugimori, K. Hiraga, Y. Hond, Influence of CPAP on reflex responses to tracheal irritation in anesthetized humans, J. Appl. Physiol. 67 (1989) 954-958.

[19] B.J. Canning, Y.L. Chou, Cough sensors. I. physiological and pharmacological properties of the afferent nerves regulating cough, Handb. Exp. Pharmacol. 187 (2009) 23-47. doi:10.1007/978-3-540-79842-2_2.

[20] A. Paintal, Mechanism of stimulation of type J pulmonary receptors., J. Physiol. 203 (1969) 511-532. doi:10.1113/jphysiol.1969.sp008877.

[21] M. Tatar, S.E. Webber, J.G. Widdicombe, Lung C-fibre receptor activation and defensive reflexes in anaesthetized cats., J. Physiol. 402 (1988) 411-420. doi:10.1113/jphysiol.1988.sp017212.

[22] M. Tatar, B. Nagyova, J. Widdicombe, Veratrine-induced reflexes and cough., Respir. Med. 85 (1991) 51-55.

[23] E. McFadden, B. Pichurko, H. Bowman, E. Ingenito, S. Burns, N. Dowling, S. J, Thermal Mapping of the Airways in Humans., J. Appl. Physiol. 58 (1985) 564-570.

[24] E. Ternesten-Hasséus, E.-L. Johansson, M. Bende, E. Millqvist, Dyspnea from exercise in cold air is not always asthma., J. Asthma. 45 (2008) 705-9. doi:10.1080/02770900802207287.

[25] M. Sue-Chu, L. Larsson, L. Bjermer, Prevalence of asthma in young cross-country skiers in central Scandinavia: Differences between Norway and Sweden, Respir. Med. 90 (1996) 99105. doi:10.1016/S0954-6111(96)90206-1. 
[26] J.H. Hull, L. Ansley, P. Robson-Ansley, J.P. Parsons, Managing respiratory problems in athletes, Clin. Med. (Northfield. II). 12 (2012) 351-356. doi:10.7861/clinmedicine.12-4-351.

[27] J. Dickinson, A. McConnell, G. Whyte, Diagnosis of exercise-induced bronchoconstriction: eucapnic voluntary hyperpnoea challenges identify previously undiagnosed elite athletes with exercise-induced bronchoconstriction., Br. J. Sports Med. 45 (2011) 1126-31. doi:10.1136/bjsm.2010.072520.

[28] L. Ansley, P. Kippelen, J. Dickinson, J.H.K. Hull, Misdiagnosis of exercise-induced bronchoconstriction in professional soccer players, Allergy Eur. J. Allergy Clin. Immunol. 67 (2012) 390-395. doi:10.1111/j.1398-9995.2011.02762.x.

[29] S.D. Anderson, K. Holzer, Exercise-induced asthma: Is it the right diagnosis in elite athletes?, J. Allergy Clin. Immunol. 106 (2000) 419-428. doi:10.1067/mai.2000.108914.

[30] F. Drobnic, P. Casan, M. Banquells, R. Miralda, J. Sanchis, Cough after exercise in the elite athlete, Sport. Med. Train. Rehabil. 6 (1996) 309-315. doi:10.1080/15438629609512061.

[31] E.M. Karjalainen, A. Laitinen, M. Sue-Chu, A. Altraja, L. Bjermer, L.A. Laitinen, Evidence of airway inflammation and remodeling in ski athletes with and without bronchial hyperresponsiveness to methacholine, Am. J. Respir. Crit. Care Med. 161 (2000) 2086-2091. doi:10.1164/ajrccm.161.6.9907025.

[32] A. Niimi, Structural changes in the airways: cause or effect of chronic cough?, Pulm. Pharmacol. Ther. 24 (2011) 328-333. doi:10.1016/j.pupt.2011.01.011.

[33] M.D. Kennedy, W.J. Davidson, L.E. Wong, S.L. Traves, R. Leigh, N.D. Eves, Airway inflammation, cough and athlete quality of life in elite female cross-country skiers: A longitudinal study, Scand. J. Med. Sci. Sport. 26 (2016) 835-842. doi:10.1111/sms.12527. 
[34] T. Deitmer, R. Scheffler, Nasal physiology in swimmers and swimmers' sinusitis., Acta Oncol. (Madr). 110 (1990) 286-291.

[35] M. Gelardi, M. Bonini, S. Bonini, T. Candreva, M. Fiorella, M. Ventura, Non Allergic Rhinitis In Competitive Swimmers, J. Allergy Clin. Immunol. 119 (2007).

[36] V. Bougault, L.-P. Boulet, Airway dysfunction in swimmers, Br. J. Sports Med. 46 (2012) 402406. doi:10.1136/bjsports-2011-090821.

[37] R.S. Irwin, M.H. Baumann, D.C. Bolser, L.-P. Boulet, S.S. Braman, C.E. Brightling, K.K. Brown, B.J. Canning, A.B. Chang, P. V. Dicpinigaitis, R. Eccles, W.B. Glomb, L.B. Goldstein, L.M. Graham, F.E. Hargreave, P. a. Kvale, S.Z. Lewis, F.D. McCool, D.C. McCrory, U.B.S. Prakash, M.R. Pratter, M.J. Rosen, E. Schulman, J.J. Shannon, C. Smith Hammond, S.M. Tarlo, Diagnosis and Management of Cough Executive Summary: ACCP evidence-based clinical practice guidelines., Chest. 129 (2006) 1-23. doi:10.1378/chest.129.1_suppl.1S.

[38] P. Macedo, H. Saleh, A. Torrego, J. Arbery, I. MacKay, S.R. Durham, K.F. Chung, Postnasal drip and chronic cough: An open interventional study, Respir. Med. 103 (2009) 1700-1705. doi:10.1016/j.rmed.2009.05.005.

[39] M. Tatar, J. Plevkova, M. Brozmanova, R. Pecova, M. Kollarik, Mechanisms of the cough associated with rhinosinusitis, Pulm. Pharmacol. Ther. 22 (2009) 121-126. doi:http://dx.doi.org/10.1016/j.pupt.2008.11.014.

[40] K. Collings, F. Pierce Pratt, S. Rodriguez-Stanley, M. Bemben, P. Miner, Esophageal reflux in conditioned runners, cyclists and weightlifters., Med. Sci. Sports Exerc. 35 (2003) 730-735.

[41] K. Parmelee-Peters, J. Moeller, Gastroesophageal reflux in athletes., Curr. Sports Med. Rep. 3 (2004) 107-111. 
[42] A.H. Morice, Airway reflux as a cause of respiratory disease, Breathe. 9 (2013) 257-266. doi:10.1183/20734735.000513.

[43] J.H. Hull, A. Menon, Laryngeal hypersensitivity in chronic cough, Pulm. Pharmacol. Ther. 35 (2015) 111-116. doi:10.1016/j.pupt.2015.08.008.

[44] H. Johansson, K. Norlander, L. Berglund, C. Janson, A. Malinovschi, L. Nordvall, L. Nordang, M. Emtner, Prevalence of exercise-induced bronchoconstriction and exercise-induced laryngeal obstruction in a general adolescent population., Thorax. 70 (2015) 57-63. doi:10.1136/thoraxjnl-2014-205738.

[45] Exercise-induced laryngeal obstruction: a common and overlooked cause of exertional breathlessness. Hall A, Thomas M, Sandhu G, Hull JH. Br J Gen Pract. 2016 Sep;66(650):e683-5.

[46] M.-R.G. Silva, T. Paiva, Poor precompetitive sleep habits, nutrients' deficiencies, inappropriate body composition and athletic performance in elite gymnasts, Eur. J. Sport Sci. 16 (2016) 726-735. doi:10.1080/17461391.2015.1103316.

[47] J.P. Parsons, T.S. Hallstrand, J.G. Mastronarde, D.A. Kaminsky, K.W. Rundell, J.H. Hull, W.W. Storms, J.M. Weiler, F.M. Cheek, K.C. Wilson, S.D. Anderson, An official American thoracic society clinical practice guideline: Exercise-induced bronchoconstriction, Am. J. Respir. Crit. Care Med. 187 (2013) 1016-1027. doi:10.1164/rccm.201303-0437ST.

[48] Y. Adir, A. Shupak, A. Gil, N. Peled, Y. Keynan, L. Domachevsky, D. Weiler-Ravel, SwimmingInduced Pulmonary Edema*, CHEST J. 126 (2004) 394-399.

[49] P. Jozkow, D. Wasko-Czopnik, M. Medras, L. Paradowski, Gastroesophageal Reflux Disease and Physical Activity, Sport. Med. 36 (2006) 385-391. doi:10.2165/00007256-20063605000002. 
[50] M.D. Sullivan, B.M. Heywood, D.R. Beukelman, A Treatment for Vocal Cord Dysfunction in Female Athletes: An Outcome Study, Laryngoscope. 111 (2001) 1751-1755. doi:10.1097/00005537-200110000-00016.

[51] J. Dickinson, G. Whyte, A. McConnell, Inspiratory muscle training: a simple cost-effective treatment for inspiratory stridor., Br. J. Sports Med. 41 (2007) 694-695. doi:10.1136/bjsm.2006.033654.

[52] K. Norlander, H. Johansson, C. Jansson, L. Nordvall, L. Nordang, Surgical treatment is effective in severe cases of exercise-induced laryngeal obstruction: A follow-up study, Acta Otolaryngol. 135 (2015) 1152-1159. doi:10.3109/00016489.2015.1062548.

[53] D.A. Beuther, R.J. Martin, Efficacy of a heat exchanger mask in cold exercise-induced asthma, Chest. 129 (2006) 1188-1193. doi:10.1378/chest.129.5.1188.

[54] A.M. Brenner, P. Weiser, L. Krogh, M. Loren, Effectiveness of a Portable Face Mask in Attenuating Exercise-Induced Asthma, JAMA. 244 (1980) 2196-2198.

[55] E. Millqvist, U. Bengtsson, O. Löwhagen, Combining a beta2-agonist with a face mask to prevent exercise-induced bronchoconstriction., Allergy. 55 (2000) 672-5. http://www.ncbi.nlm.nih.gov/pubmed/10921469.

[56] M. Nisar, D.P. Spence, D. West, J. Haycock, Y. Jones, M.J. Walshaw, J.E. Earis, P.M. Calverley, M.G. Pearson, A mask to modify inspired air temperature and humidity and its effect on exercise induced asthma., Thorax. 47 (1992) 446-50. http://www.pubmedcentral.nih.gov/articlerender.fcgi?artid=463810\&tool=pmcentrez\&ren dertype=abstract.

[57] H. Gong, J.F. Bedi, S.M. Horvath, Inhaled Albuterol does Not Protect Against Ozone Toxicity in Nonasthmatic Athletes, Arch. Environ. Heal. An Int. J. 43 (1988) 46-53. 
doi:10.1080/00039896.1988.9934373.

[58] E. Peters, J. Goetzsche, B. Grobbelaar, T. Noakes, Vitamin C supplementation reduces the incidence of postrace symptoms of upper-respiratory-tract infection in ultramarathon runners, Am. J. Clin. Nutr. 57 (1993) 170-174.

[59] I. Helenius, A. Lumme, J. Öunap, Y. Obase, P. Rytilä, S. Sarna, A. Alaranta, V. Remes, T. Haahtela, No effect of montelukast on asthma-like symptoms in elite ice hockey players, Allergy. 59 (2004) 39-44. doi:10.1046/j.1398-9995.2003.00353.x. 


\section{TABLE FOOTNOTES}

Table 1. Potential mechanisms in the regulation of cough during exercise. Reproduced from (Widdicombe et al. [17]). Definition of abbreviations: SAR, slowly adapting airway mechanoreceptor.

Table 2. Studies evaluating cough in athletic individuals. Definition of abbreviations: AHR, airways hyper-reactivity; EIA, exercise-induced asthma; EVH, eucapnic voluntary hyperpnoea; LCQ, Leicester cough questionnaire

Table 3. Treatments studied for cough in athletic individuals. Adapted from Boulet et al. [9]. 
FIGURE LEGENDS

Figure 1. Schematic of potential mechanisms underpinning cough in athletes. 


\section{TABLES}

Table 1.

Down regulation of cough

SARs activation

C-fibre activation

Chest wall sensor activation

Increase in plasma catecholamine levels
Up regulation of cough

SARs activation

Heat loss

Hyperosmolality

Increased central deposition of tussives 
Table 2.

\begin{tabular}{|c|c|c|c|c|c|}
\hline Author & Date & Population & Method & $n$ & Conclusions \\
\hline Drobnic et al.[30] & 1996 & $\begin{array}{l}\text { Elite athletes ( } 31 \% \text { aquatic } \\
\text { sports, } 69 \% \text { non-athletic) }\end{array}$ & $\begin{array}{l}\text { Looked at presence of cough by questionnaire } \\
\text { and observation, presence of EIA by history and } \\
\text { examination and BR by methacholine challenge. }\end{array}$ & 130 & $\begin{array}{l}\text { The presence of cough in athletes has low } \\
\text { sensitivity and high specificity for the prediction } \\
\text { of EIA. }\end{array}$ \\
\hline Rundell et al.[2] & 2001 & Elite athletes & $\begin{array}{l}\text { Spirometry was performed pre and post a sport } \\
\text { and environment specific exercise challenge. } \\
\text { Athletes grouped as EIA +ve, EIA -ve and EIA } \\
\text { borderline. Athletes also completed a EIA } \\
\text { symptom questionnaire. }\end{array}$ & 158 & $\begin{array}{l}39 \% \text { of }+ \text { ve athletes and } 41 \% \text { of -ve athletes } \\
\text { reported } 2 \text { or more symptoms. Post-race cough } \\
\text { was the most commonly reported symptom. } \\
\text { Sensitivity/ specificity analysis demonstrated a } \\
\text { lack of effectiveness of self-reported symptoms } \\
\text { to identify ElA + ver athletes. }\end{array}$ \\
\hline Turcotte et al.[3] & 2003 & $\begin{array}{l}\text { High level athletes training in } \\
\text { different conditions and } \\
\text { sedentary controls }\end{array}$ & $\begin{array}{l}\text { Subjects answered questions on exercise } \\
\text { induced symptoms including cough nociceptive } \\
\text { sensations. They also performed methacholine } \\
\text { challenges. }\end{array}$ & $\begin{array}{l}100 \\
\text { athletes, } \\
50 \\
\text { controls }\end{array}$ & $\begin{array}{l}\text { Athletes training in cold air reported more } \\
\text { exercise induced cough. Symptom } \\
\text { questionnaires may help to detected AHR, but } \\
\text { not in some subgroups such as swimmers and } \\
\text { triathletes. }\end{array}$ \\
\hline Turcotte et al. [4] & $2003 a$ & $\begin{array}{l}\text { Athletes (Exercising in cold, } \\
\text { dry, humid or mixed dry \& } \\
\text { humid air) }\end{array}$ & $\begin{array}{l}\text { Athletes completed questionnaires on their } \\
\text { respiratory condition including cough. }\end{array}$ & $\begin{array}{l}698(107 \\
\text { with } \\
\text { asthma) }\end{array}$ & $\begin{array}{l}\text { Perception of exercise-induced symptoms was } \\
\text { not influences by the duration of training or } \\
\text { environment. A minority of asthmatic athletes } \\
\text { report symptoms. Cough and wheezing is more } \\
\text { commonly reported in the asthmatic athletes. }\end{array}$ \\
\hline Turmel et al. [6] & 2012 & $\begin{array}{l}\text { Elite winter athletes and } \\
\text { sedentary controls }\end{array}$ & $\begin{array}{l}\text { At } 3 \text { time points; summer, autumn, and winter, } \\
\text { subjects performed capsaicin challenge, cough } \\
\text { questionnaires, spirometry, EVH and } \\
\text { methacholine challenge. }\end{array}$ & $\begin{array}{l}53 \\
\text { athletes, } \\
33 \\
\text { controls }\end{array}$ & $\begin{array}{l}\text { Prevalence of cough immediately post and 2-8 } \\
\text { hours post was higher in athletes and more } \\
\text { frequently reported in winter. Cough was not } \\
\text { related to cough reflex sensitivity to capsaicin, } \\
\text { bronchoconstriction or airway inflammation in } \\
\text { the majority of athletes. }\end{array}$ \\
\hline Kennedy et al. [33] & 2016 & $\begin{array}{l}\text { Female elite cross-country } \\
\text { skiers }\end{array}$ & $\begin{array}{l}\text { Sputum induction, LCQ, Recovery Stress } \\
\text { Questionnaire at } 3 \text { time points; summer, } \\
\text { autumn and winter. }\end{array}$ & 18 & $\begin{array}{l}\text { Airway inflammation and cough symptoms } \\
\text { significantly increase during a competitive year. } \\
\text { Incidence of cough appears related to the total } \\
\text { amount of training and is worse during the } \\
\text { winter months when athletes are training and } \\
\text { racing in cold dry air. }\end{array}$ \\
\hline
\end{tabular}


Table 3

\begin{tabular}{|c|c|c|c|c|c|c|c|c|}
\hline Author & Date & $\begin{array}{l}\text { Study } \\
\text { Design }\end{array}$ & Athletes & $\begin{array}{c}\text { Gender } \\
\text { (M:F) }\end{array}$ & $\begin{array}{c}\text { Control } \\
\text { Group }\end{array}$ & Intervention & Outcome & $\begin{array}{l}\text { Quality of } \\
\text { Evidence }\end{array}$ \\
\hline Gong et al [57] & 1988 & $\mathrm{RCT}$ & $\begin{array}{l}15 \text { cyclists and } \\
\text { triathletes with no } \\
\text { history of asthma or } \\
\text { current use of inhaler } \\
\text { medication }\end{array}$ & $14: 1$ & No & $\begin{array}{l}180 \text { mcg Albuterol vs } \\
\text { placebo. } 40 \mathrm{~km} \text { time trial in } \\
\text { polluted air (ozone } 0.21 \\
\text { ppm) or filtered air } \\
\text { environment }\end{array}$ & $\begin{array}{l}\text { Pre-exercise use of Albuterol did not } \\
\text { attenuate the effect of } 0.21 \mathrm{ppm} \text { ozone on } \\
\text { cough, exercise performance, lung function or } \\
\text { reactivity to histamine. }\end{array}$ & Moderate \\
\hline Peters et al [58] & 1993 & $\mathrm{RCT}$ & $\begin{array}{l}84 \text { endurance } \\
\text { runners and } 73 \text { non- } \\
\text { athlete controls }\end{array}$ & $\begin{array}{l}82: 2 \\
\text { (athletes) }\end{array}$ & Yes & $\begin{array}{l}600 \text { mg Vitamin C daily vs. } \\
\text { placebo containing citric acid }\end{array}$ & $\begin{array}{l}\text { Duration of symptoms was shorter in the } \\
\text { Vitamin C supplemented runners. Decreased } \\
\text { incidence of cough symptoms for } 3 \text { weeks } \\
\text { post race. }\end{array}$ & Moderate \\
\hline Helenius et al [59] & 2004 & $\mathrm{RCT}$ & 16 Ice Hockey players & $18: 1$ & No & $\begin{array}{l}4 \text { weeks } 10 \text { mg Montelukast, } \\
1 \text { week wash out and } 4 \\
\text { weeks placebo }\end{array}$ & $\begin{array}{l}\text { No difference between placebo and } \\
\text { montelukast in weekly or monthly reports of } \\
\text { cough. }\end{array}$ & Moderate \\
\hline Bordeleau et al [7] & 2014 & $\mathrm{RCT}$ & $\begin{array}{l}22 \text { Cross Country } \\
\text { skiers who reported } \\
\text { exercise respiratory } \\
\text { symptoms }\end{array}$ & $10: 12$ & No & $\begin{array}{l}80 \text { mcg Ipratropium vs. } \\
\text { placebo prior to cross } \\
\text { country skiing ( } 3 \text { min sprint } \\
\text { preceded by } 30 \text { min warm- } \\
\text { up) }\end{array}$ & $\begin{array}{l}\text { No change in perception of cough or cough } \\
\text { frequency. However, sub group of } \\
\text { participants did have a beneficial reduction in } \\
\text { cough frequency). }\end{array}$ & Moderate \\
\hline
\end{tabular}




\section{FIGURES}

Figure 1.

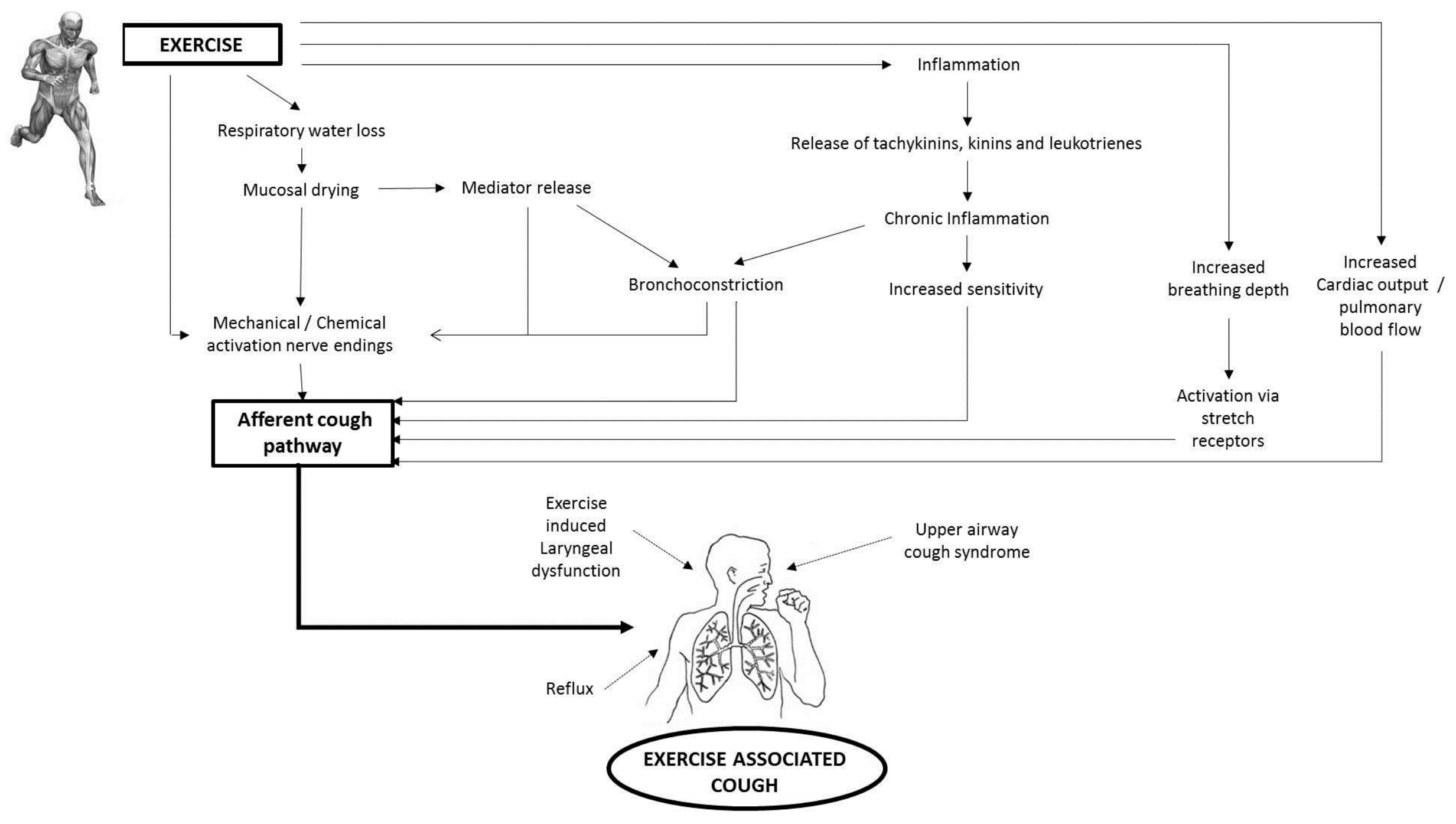

